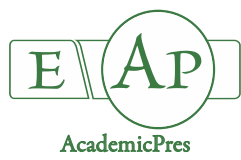

\title{
Physiological Responses of Paneer-Booti (Withania coagulans Dunal) to NaCl Stress Under Tissue Culture Conditions
}

\author{
Aysan GHAHREMANI ${ }^{1}$, Ebrahim GANJI MOGHADAM ${ }^{2 *}$, \\ Maryam TATARI ${ }^{3}$, Susan KHOSROYAR ${ }^{4}$ \\ ${ }^{1}$ Islamic Azad University, Department of Horticultural Sciences, Shirvan Branch, Shirvan, Iran; ghahremanye@yahoo.com \\ ${ }^{2}$ Khorasan Razavi Agricultural and Natural Resources Research and Education Center, Crop and Horticultural Science Research Department, \\ AREEO, Mashhad, Iran; eganji@hotmail.com (*corresponding author) \\ ${ }^{3}$ Islamic Azad University, Agronomy Department, Shirvan Branch, Shirvan, Iran; maryamtatari@yahoo.com \\ ${ }^{4}$ Islamic Azad University, Department of Chemical Engineering, Quchan Branch, Quchan, Iran; susankhosroyar@yahoo.com
}

\begin{abstract}
Salinity is one of the major abiotic stresses, which affects physiological traits and reduces plant productivity. Paneer-booti (Withania coagulans Dunal) is a medicinal and aromatic plant belonging to the Solanaceae family, which is an endemic plant in the Middle East. In this study, the effect of different salt concentrations (0, 50, 100, 150, 200, and $250 \mathrm{mM} \mathrm{NaCl})$ on antioxidant enzymes activity such as catalase (CAT), peroxidase (POD), and ascorbate peroxidase (APX), proline, phenols, and flavonoids contents, relative water content (RWC), electrolyte leakage, $\mathrm{Na}^{+}$and $\mathrm{K}^{+}$concentrations, and chlorophyll fluorescence of Paneer-booti were studied. Results indicated that the effect of $\mathrm{NaCl}$ stress was significant on all traits. By increasing $\mathrm{NaCl}$, to $250 \mathrm{mM}$ levels, enhance activity of CAT (76.75\%), POD (56.49\%), and APX (44.77\%), proline (79.56\%), phenols (56.15\%), electrolyte leakage (76.74\%), $\mathrm{Na}^{+}$(54.70\%), and minimum fluorescence (Fo) (44.94\%) was observed while decreased RWC (11.33\%), $\mathrm{K}^{+}$concentration $(50.8 \%), \mathrm{K}^{+} / \mathrm{Na}^{+}$ratio $(77.77 \%)$, and $\mathrm{Fv} / \mathrm{Fm}$ ratio $(67.5 \%)$ compared to the control treatment was noted. By increasing electrolyte leakage enhance in the rate of antioxidant enzymes activity (CAT, POD, and APX), proline, phenols, and flavonoids contents, and $\mathrm{Na}^{+}$concentration was observed. The rate of $\mathrm{K}^{+} / \mathrm{Na}^{+}$ratio is very important under salinity condition, so, the trait had a negative correlation with antioxidant enzyme activities, proline, phenols, and flavonoids contents. Our results revealed that Paneer-booti plantlet had a high tolerant to the $\mathrm{NaCl}$ stress due to the fact high level of the enzymatic and non-enzymatic antioxidant activities under higher levels of salinity.
\end{abstract}

Keywords: antioxidant activity; chlorophyll fluorescence; $\mathrm{Na}^{+} / \mathrm{K}^{+}$ratio; proline content; salt stress

Abbreviations: CAT-Catalase; POD-Peroxidase; APX-Ascorbate peroxidase; RWC-Relative water content; ROS-Reactive oxygen species

\section{Introduction}

Paneer-booti (Withania coagulans Dunal) is a selfpropelled plant in Iran and important plant of the traditional Iranian and Indian system of medicine. In addition, recently, gained a lot of attention in the world because of its protective role in neurodegeneration and repair of synapses (Sabir et al., 2012). The twenty-three known Withania species are widely distributed in the drier parts of tropical and sub-tropical zones. Among all Withania species, only two species: Withania somnifera and Withania coagulans are of economical and medicinal importance as they are used and cultivated in several regions (Valizadeh and Valizadeh, 2011; Kumar Shrivastava and Sahu, 2013). Paneer-booti is native of Mediterranean region in North Africa and is widely distributed in Pakistan, India, Sri Lanka, South Africa, Iraq, Iran, Syria, and Turkey (Kumar Shrivastava and Sahu, 2013).

Plants encounter several abiotic and biotic stresses in their natural surroundings. The abiotic stresses such as low temperature, drought, and high salinity are common unfavorable conditions that adversely affect plant growth and crop production (Sabir et al., 2012). Salinity is one of the major abiotic stresses in arid and semi-arid regions that substantially reduce the yield of major crops by more than 50\% (Bybordi, 2010). Approximately 800 million hectares 
1366

of global farmland is saline (Vargas et al., 2018). Previous research have shown that there are about 25 million hectares of saline and alkaline areas in Iran constituting almost $15 \%$ of the country's area, $30 \%$ of its plains and plateaus and more than $50 \%$ of the irritable and agricultural lands. Salinity in soil and irrigation water should be considered a serious problem in Iran (Jafari et al., 2018).

Salinity stress leads to a series of modifications in physiological attributes of plant such as antioxidant enzymes activity, photosynthesis, photorespiration, and synthesis of amino acid, protein, and carbohydrate (Abogadallah, 2010). It is generally accepted that stressinduced deregulation of plant metabolism leads to the enhanced production of reactive oxygen species (ROS). To avoid cellular damage due to ROS generation, plants produce a number of antioxidant enzymes that induce and provide secondary protection against oxidative stress (Abogadallah, 2010). ROS are generated from by abiotic stresses such as salt stress must be scavenged for the security of essential macromolecules from destructive effects of ROS and maintenance of normal growth (Kaur and Zhawar, 2016).

Moreover, catalase (CAT) is the other enzyme that converts two molecules of $\mathrm{H}_{2} \mathrm{O}_{2}$ to water and oxygen (Abogadallah, 2010). Changes in activities of different antioxidant enzymes under salinity were reported in Paneerbooti (Sabir et al., 2012), corn (Carrasco-Ríos and Pinto, 2014), and stevia (Aghighi Shahverdi et al., 2017). These reports show that the induction of ROS-scavenging enzymes, such as SOD, POD, and CAT, is the most general defense mechanism of salinity tolerance for detoxifying ROS (Abogadallah, 2010). Plants grown under salinity stress also accumulate compatible solutes such as free proline to function as osmotic buffers lowering the cellular osmotic potential to sustain water absorption from saline solutions and to restore intracellular ion homeostasis; they also exhibit ROS scavenging properties (Almeida et al., 2017). Apart from these responses, salinized plants also display morphological and developmental adjustments (Sabir et al., 2012).

Optimized agricultural practices for this plant are available but the management and responses of Paneerbooti under salt stress conditions are not known. In vitro cultures could provide a convenient and alternative way to test the salinity responses under controlled conditions. The aim of the current study was to assess the physiological responses such as the activity of antioxidant enzymes, RWC, ionic content, and chlorophyll fluorescence of Paneer-booti to different salinity $(\mathrm{NaCl})$ stress.

\section{Materials and Methods}

\section{Experimental design and plant material}

The study in order to provide a rapid and useful method for propagation of Paneer-booti (Withania coagulans Dunal) medical plant under in-vitro condition was conducted in tissue culture laboratory of Khorasan Razavi Agricultural and Natural Resources Research and Education Center in 2017. The experiment was designed in a completely randomized design (CRD) with four replicates. In this case salt concentrations included 0,50 ,
$100,150,200$, and $250 \mathrm{mM}$ was used for imposing stress conditions. Paneer-booti samples were collected from the natural habitat of this plant in Sistan and Baluchistan Province of Iran. For sterilization of seeds, $70 \%$ alcohol was used for 5 minutes and $10 \%$ sodium hypochlorite for 10 minutes. Then it was washed in sterile water in three steps and cultured in MS medium including BAP. Salinity treatment was applied in cultured in MS medium. The culture plates were placed in a growth room with 16 hours of light at $22^{\circ} \mathrm{C}$ and eight hours of darkness at $18{ }^{\circ} \mathrm{C}$ for 3 weeks. In rooting stage, indole-3-butyric acid (IBA) and naphthaleneacetic acid (NAA) was added to MS medium. In order to determine of best concentration of IBA and NAA, a pilot experiment in five concentrations $(0,0.5,1$, $\left.1.5,2 \mathrm{mg} \mathrm{L}^{-1}\right)$ were tested. These results showed that the best concentrations of IBA and NAA were $0.5 \mathrm{mg} \mathrm{L}^{-1}$, that was used this data in the experiment for proliferation and rooting. After 40 days, plantlets were transferred to adaptation room. At this stage, plantlet were transferred to pots containing cocopeat and perlite $(1: 1)$ and stored under $85 \%$ relative humidity, $25^{\circ} \mathrm{C}$ temperature, and 3000 lux luxurious conditions for 30 days. The whole plants were harvested and were placed in the freezer used for further assays.

Extraction and assay of enzymatic antioxidant activities

Antioxidant enzyme extraction was determined using to the method of Sunohara and Matsumoto (2004) with slight modifications. $200 \mathrm{mg}$ of leaves was sliced and homogenized in $10 \mathrm{~mL}$ of $25 \mathrm{mM} \mathrm{K}-\mathrm{P}$ buffer $(\mathrm{pH} 7.8)$ containing $1 \mathrm{mM}$ AsA, $0.4 \mathrm{mM}$ EDTA and 2\% PVPP at $4{ }^{\circ} \mathrm{C}$ for $1 \mathrm{~min}$. The homogenate solution was centrifuged at $15,000 \times$ g at $4{ }^{\circ} \mathrm{C}$ for $20 \mathrm{~min}$ and the supernatant was filtered through filter paper (Whatman No.1, England). The filtrate was collected to determine the activities of CAT (EC 1.11.1.6), POD (EC 1.11.1), and APX (EC 1.11.1.11) (Abogadallah, 2010).

CAT activity was determined according to the method of Sunohara and Matsumoto (2004) with some modifications. It was assayed in a $2 \mathrm{~mL}$ reaction mixture comprising of $1.9 \mathrm{~mL}$ of $50 \mathrm{mM} \mathrm{K}-\mathrm{P}$ buffer ( $\mathrm{pH} 7.0$ ) containing $25 \mathrm{mM} \mathrm{H}_{2} \mathrm{O}_{2}$ and $0.1 \mathrm{~mL}$ of enzyme extract for $1 \mathrm{~min}$. CAT activity was measured in terms of the decomposition of $\mathrm{H}_{2} \mathrm{O}_{2}$ at $240 \mathrm{~nm}$ and activity calculated per leaf protein in a minute.

POD activity was assayed by the method proposed by Chance and Maehly (1995). An alcoholic liquid of the tissue extract $(100 \mu \mathrm{L})$ was added to $3 \mathrm{~mL}$ of assay solution including $3 \mathrm{~mL}$ of reaction mixture containing $13 \mathrm{mM}$ guaiacol, $5 \mathrm{mM} \mathrm{H}_{2} \mathrm{O}_{2}$, and $50 \mathrm{mM}$ sodium $(\mathrm{Na})$-phosphate (pH 6.5). An increase in the optical density at $470 \mathrm{~nm}$ for 1 min at $25^{\circ} \mathrm{C}$ was recorded using spectrophotometer.

APX activity was determined according to the method of Sunohara and Matsumoto (2004) with some modifications. It was assayed in a $2 \mathrm{~mL}$ reaction mixture comprising $0.02 \mathrm{~mL}$ of $10 \mathrm{mM} \mathrm{H}_{2} \mathrm{O}_{2}, 0.5 \mathrm{~mL}$ of $1 \mathrm{mM}$ ascorbic acid, $0.5 \mathrm{~mL}$ of $100 \mathrm{mM} \mathrm{K-P}$ buffer ( $\mathrm{pH} 7.0), 0.5$ $\mathrm{mL}$ of $0.4 \mathrm{mM}$ EDTA, $0.38 \mathrm{~mL}$ of distilled water and 0.1 $\mathrm{mL}$ of enzyme extract for $1 \mathrm{~min}$. It was measured in terms of disappearance/decomposition of AsA at 290 nanometers.

Free proline content 
Leaf free proline content was determined by using Bates et al. (1973) method, $0.5 \mathrm{~g}$ of the fresh leaf was ground with quarts in porcelain pestle and mortar and treated with 10 $\mathrm{mL}$ sulfosalicylic acid, and the homogenate was centrifuged at $13000 \mathrm{~g}$ for $10 \mathrm{~min}$. The red surface layer and standard samples were simultaneously placed in a spectrophotometer and the absorption of the samples was determined at the wavelength of 520 nanometres. The amount of proline content $(\mu \mathrm{mol} / \mathrm{g} \mathrm{FW})$ was calculated by using regression equations and the standard curves.

\section{Non-enzymatic antioxidant}

Measurement of total phenolic compounds was conducted according to the following: $0.2 \mathrm{~g}$ of sample was mixed with $20 \mathrm{~mL}$ boiled water using a tube, which was then placed for 1 hour in a water bath. Then $1 \mathrm{~mL}$ of extract was mixed with $5 \mathrm{~mL}$ indicator of Folin-Denis and $10 \mathrm{~mL}$ sodium carbonate $\left(\mathrm{NaCO}_{3} 35 \%\right)$ and was brought up to volume using a $100 \mathrm{~mL}$ volumetric flask. The solution was left undisturbed under the room temperature for $45 \mathrm{~min}$. Finally, the absorption of samples was calculated using the standard curve of gallic acid (Blainski et al., 2013). Flavonoid contents were determined following the method described by Zhishen et al. (1999); the absorbance was measured at 510 nanometres, and the amount of flavonoids was expressed in equivalents of catechin (mg eq. $\mathrm{C} \mathrm{g}^{-1} \mathrm{DW}$ ), used as a standard.

\section{Measurements of Relative Water Content}

Relative water content (RWC) of the control shoots as well as the shoots with as earlier (Sangwan et al., 1994). RWC was calculated by using the equation 1 :

Equation 1: RWC $(\%)=(\mathrm{FW}-\mathrm{DW}) / \mathrm{TW}-\mathrm{DW} \times 100$

Whereas FW: fresh weight, DW: dry weight; and TW: turgid weight

\section{Electrolyte leakage}

Electrolyte leakage was determined according to the method of Chan and Maehly (1995). Ten discs of leaf sample were placed in an Erlenmeyer flask containing 25 $\mathrm{mL}$ of deionized water at $25^{\circ} \mathrm{C}$ for $30 \mathrm{~min}$. The initial conductivity (E1) of the mixture was measured with a conductivity meter (Five Easy FE 30, Mettler Toledo, Switzerland). Then, the contents in the Erlenmeyer flask were heated at $98{ }^{\circ} \mathrm{C}$ for 15 minute, and the conductivity (E2) the mixture was re-measured after cooling. EL was determined using the formula: Membrane permeability units were calculated by equation:

$$
\mathrm{EL}(\%)=(\mathrm{E} 1 / \mathrm{E} 2) \times 100
$$

$\mathrm{Na}^{+}$and $\mathrm{K}^{+}$contents
The measurement of $\mathrm{Na}^{+}$and $\mathrm{K}^{+}$contents was performed using flame photometry (Enders and Lehmann, 2012). In this method, by using the standard curve and the equation 3 were calculated $\mathrm{Na}^{+}$and $\mathrm{K}^{+}$contents in different organs (Aghighi Shahverdi et al., 2017).

Equation 3: $\quad A=y \times 100 / 1000 \times 1000 / w$

Whereas y: number of achieved from the standard curve $\left(\mathrm{mg} \mathrm{kg}^{-1}\right) ; \mathrm{A}: \mathrm{Na}^{+}$or $\mathrm{K}^{+}$content; $\mathrm{w}$ : primary dry weight $(\mathrm{g})$.

\section{Chlorophyll fluorescence}

Chlorophyll fluorescence was measured with chlorophyll fluorometer, PAM-2000, Walz, Germany according to the method of Abdeshahian et al. (2010).

\section{Statistical analysis}

Data were expressed as means \pm standard deviation (SD). The means were compared by using the one-way and multivariate analysis of variances (ANOVA) followed by least significant difference (LSD) tests. The difference between individual means was deemed to be significant at $\mathrm{P}<0.05$.

\section{Results and Discussion}

\section{Effects of salinity on enzymatic antioxidant activities}

The effect of salinity was significant on CAT $(\mathrm{P} \leq 0.01)$, POD $(\mathrm{P} \leq 0.05)$, and APX $(\mathrm{P} \leq 0.05)$ activities (Table 1$)$. Results indicated that salinity stress significantly increased the activity of CAT, POD, and APX. In $250 \mathrm{mM} \mathrm{NaCl}$, the increasing activity of CAT, POD, and APX were 76.75, 56.49 , and $44.77 \%$ compared to the control (Table 2). Salt stress is a major environmental factor which prevents crop plants from attaining their full genetic potential; therefore, salt stress in plant induces several growth limitations (Taibi et al., 2016). In the current study, results illustrated that the salinity stress $(\mathrm{NaCl})$ caused an increase in antioxidant enzyme activities (e.g., CAT, POD, and APX) (Table 2). In response to salinity, plants have developed a series of enzymatic (e.g., CAT, POD, and APX) and non-enzymatic (ascorbate, flavonoids, and other phenolic compounds) detoxification systems to counteract reactive oxygen species and protect cells from oxidative damage (Ozgur et al., 2013). Superoxide dismutase (SOD) is the primary scavenger, which localized in chloroplasts, mitochondria, peroxisomes, and cytosol. SOD catalyzes the disproportion of two $\mathrm{O}^{2-}$ radicals to $\mathrm{H}_{2} \mathrm{O}_{2}$ and $\mathrm{O}_{2}$ (Perry et al., 2010). $\mathrm{H}_{2} \mathrm{O}_{2}$ is detoxified to two molecules of water in the glutathione-ascorbate cycle by ascorbate peroxidase in cooperation with dehydroascorbate reductase and glutathione reductase, and regenerate the ascorbic acid

Table 1 . Analysis of variance on some physiological traits of Paneer-booti (Withania coagulans Dunal) under salinity stress

\begin{tabular}{|c|c|c|c|c|c|c|c|c|c|}
\hline & & \multicolumn{8}{|c|}{ Mean square (MS) } \\
\hline S.O.V & $\mathrm{df}$ & CAT & POD & APX & Proline & Phenols & Flavonoids & RWC & Electrolyte leakage \\
\hline Salinity & 5 & $1.61^{* *}$ & $1.67^{*}$ & $34.7^{*}$ & $0.26^{* *}$ & $837.1^{* *}$ & $116.3^{* *}$ & $35.2^{*}$ & $1620.7^{* *}$ \\
\hline Error & 12 & 0.02 & 0.42 & 12.1 & 0.02 & 4.64 & 1.58 & 7.12 & 16.16 \\
\hline C.V (\%) & - & 9.09 & 19.6 & 26.15 & 23.37 & 4.07 & 15.52 & 4.04 & 9.04 \\
\hline
\end{tabular}


Table 2. Effect of salinity levels $(0,50,100,150,200$, and $250 \mathrm{mM} \mathrm{NaCl})$ on some physiological traits of Paneer-booti (Withania coagulans Dunal)

\begin{tabular}{|c|c|c|c|c|c|c|c|c|}
\hline $\begin{array}{c}\text { Salinity } \\
(\mathrm{mM} \\
\mathrm{NaCl})\end{array}$ & $\begin{array}{c}\text { CAT } \\
\left(\mathrm{U} \text { min.mg protein }^{-1}\right)\end{array}$ & $\begin{array}{c}\text { POD } \\
(\mathrm{U} \text { min.mg } \\
\left.\text { protein }^{-1}\right)\end{array}$ & $\begin{array}{c}\text { APX } \\
(\mathrm{U} \text { min.mg } \\
\left.\text { protein }^{-1}\right)\end{array}$ & $\begin{array}{c}\text { Proline } \\
\left(\mu \mathrm{mol} \mathrm{g}^{-1} \mathrm{FW}\right)\end{array}$ & $\begin{array}{c}\text { Phenols } \\
\left(\text { mg Galic }{ }^{1}{ }^{F W}\right)\end{array}$ & $\begin{array}{c}\text { Flavonoids } \\
\left(\mathrm{mg} \text { Qersin } \mathrm{g}^{1} \mathrm{FW}\right)\end{array}$ & $\begin{array}{c}\text { RWC } \\
(\%)\end{array}$ & $\begin{array}{l}\text { Electrolyte } \\
\text { leakage (\%) }\end{array}$ \\
\hline Control & $0.53 \pm 0.06 \mathrm{~d}$ & $1.24 \pm 0.13 \mathrm{~b}$ & $9.15 \pm 2.3 \mathrm{c}$ & $0.19 \pm 0.03 \mathrm{~d}$ & $36.53 \pm 1.3 \mathrm{e}$ & $1.48 \pm 0.25 \mathrm{~d}$ & $70.30 \pm 1.0 \mathrm{a}$ & $18.56 \pm 2.0 \mathrm{~d}$ \\
\hline 50 & $1.19 \pm 0.14 \mathrm{c}$ & $1.53 \pm 0.25 \mathrm{~b}$ & $10.10 \pm 2.7 b c$ & $0.45 \pm 0.13 \mathrm{~cd}$ & $43.25 \pm 0.94 \mathrm{~d}$ & $1.74 \pm 0.29 \mathrm{~d}$ & $68.90 \pm 1.6 \mathrm{a}$ & $22.96 \pm 3.4 \mathrm{~d}$ \\
\hline 100 & $1.94 \pm 0.04 \mathrm{~b}$ & $2.15 \pm 0.29 \mathrm{ab}$ & $11.82 \pm 1.0 \mathrm{abc}$ & $0.64 \pm 0.04 \mathrm{bc}$ & $44.45 \pm 1.6 \mathrm{~d}$ & $5.15 \pm 0.47 c$ & $67.76 \pm 1.8 \mathrm{ab}$ & $38.60 \pm 1.5 \mathrm{c}$ \\
\hline 150 & $2.16 \pm 0.11 \mathrm{ab}$ & $2.21 \pm 0.13 \mathrm{ab}$ & $15.67 \pm 0.86 \mathrm{ab}$ & $0.82 \pm 0.07 \mathrm{ab}$ & $50.88 \pm 1.0 \mathrm{c}$ & $11.01 \pm 0.81 \mathrm{~b}$ & $63.96 \pm 1.8 \mathrm{bc}$ & $45.36 \pm 2.6 \mathrm{c}$ \\
\hline 200 & $2.39 \pm 0.08 \mathrm{a}$ & $2.85 \pm 0.53 \mathrm{a}$ & $16.75 \pm 2.9 \mathrm{a}$ & $0.93 \pm 0.08 \mathrm{a}$ & $58.70 \pm 1.4 \mathrm{~b}$ & $12.79 \pm 0.91 \mathrm{~b}$ & $62.66 \pm 1.1 \mathrm{c}$ & $61.33 \pm 2.3 b$ \\
\hline 250 & $2.28 \pm 0.04 \mathrm{a}$ & $3.20 \pm 0.61 \mathrm{a}$ & $16.57 \pm 0.94 \mathrm{a}$ & $0.93 \pm 0.08 \mathrm{a}$ & $83.31 \pm 0.86 \mathrm{a}$ & $16.49 \pm 1.1 \mathrm{a}$ & $62.33 \pm 1.55 \mathrm{c}$ & $79.80 \pm 1.0 \mathrm{a}$ \\
\hline LSD & 0.28 & 1.16 & 6.21 & 0.27 & 3.83 & 2.24 & 4.74 & 7.15 \\
\hline
\end{tabular}

Values (means of three replicates \pm SE) of each parameter followed by at least one same letter are not significantly different at P $<0.05$ based on least significant difference (LSD).

CAT: catalase activity; POD: peroxidase activity; APX: ascorbate peroxidase activity; RWC: relative water content;

(Shereefa and Kumaraswamy, 2016; Abogadallah, 2010). The role of antioxidant enzymes as an important component of the plant response mechanism to salinity, by the detoxification of superoxide and $\mathrm{H}_{2} \mathrm{O}_{2}$, has been already reported (Esfandiari et al., 2007; Jaleel et al., 2007). In addition, Taibi et al. (2016) reported that CAT and APX are the most effective antioxidant enzymes in preventing cell damage due to oxidative stress. These two enzymes revealed great importance in regulating $\mathrm{H}_{2} \mathrm{O}_{2}$ intracellular levels (Azevedo-Neto et al., 2006). A similar result was obtained in the present experiment.

\section{Effect of salinity on proline}

Salinity stress significantly affects proline content (Table 1). Stress significantly increased proline content; however, the amount of proline was in the range of $0.19 \mu \mathrm{mol} \mathrm{g} \mathrm{FW}$ (non-stress) and $0.93 \mu \mathrm{mol} \mathrm{g} \mathrm{g}^{-1} \mathrm{FW}(250 \mathrm{mM} \mathrm{NaCl})$. Enhanced accumulation of proline in plantlet treated with salts was observed at all concentrations (Table 2). Enhanced accumulation of proline in plantlet treated with $\mathrm{NaCl}$ was observed. A noticeable increase in the proline content $(57.7 \%)$ at even the lowest concentration $(50 \mathrm{mM} \mathrm{NaCl})$ was observed in treated plantlet compared to the control treatment (Table 2). Plants have evolved diverse strategies of acclimatization and avoidance to cope with adverse environmental conditions. Interestingly, among various compatible solutes, there are many reports of enhanced proline accumulation during stress conditions (Sabir et al., 2012). In the literature, the role of proline in stressed plants is often explained by its property as an osmolyte and its ability to balance water stress (Sangwan et al., 1994). Proline acts as a suitable osmoprotectant and accumulates in high concentrations without disturbing the intracellular and attempts to preserve the activity of enzymes (Sabir $e t$ al., 2012). Proline has also been shown to protect plants against singlet oxygen- and free radical-induced damage (Alia et al., 1991). Due to its action as a singlet-oxygen quencher and scavenger of $\mathrm{OH}^{-}$radicals, proline is able to stabilize protein, DNA, and membranes. Accumulation of proline-rich proteins, and particularly proline residues in proteins, provides additional protection against oxidative stress. In addition, other possible positive roles of proline under stress have also been proposed, including the regulation of cytosolic $\mathrm{pH}$ and of the $\mathrm{NAD} / \mathrm{NADH}$ ratio, and it stores energy that can be rapidly broken down and used when the plant is relieved of stress (Mattioli et al., 2009).

Effect of salinity on non-enzymatic antioxidants
Non-enzymatic antioxidants (phenols and flavonoids) significantly affected by salinity stress. The Results showed a significant increase in the rate of phenols and flavonoids,

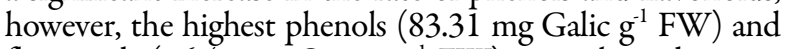
flavonoids (16.49 mg Qersin $\mathrm{g}^{-1} \mathrm{FW}$ ) was achieved in 250 $\mathrm{mM} \mathrm{NaCl}$ and the lowest amounts $\left(36.53 \mathrm{mg}\right.$ Galic $\mathrm{g}^{-1} \mathrm{FW}$ and $1.48 \mathrm{mg}$ Qersin $\mathrm{g}^{-1} \mathrm{FW}$, respectively) was observed in non-stress condition (Table 2). In addition to enzymatic antioxidants, plants possess a variety of non-enzymatic molecules which play a substantial role in counteracting oxidative stress. These non-enzymatic antioxidants included ascorbic acid, carotenoids, flavonoids, and phenolic compounds (Lee et al., 2014). Flavonoids represent the main and most complex subgroup of polyphenols with a wide array of biological functions including lipid peroxidation inhibition (Di Ferdinando et al., 2012). In the present study, $\mathrm{NaCl}$ stress led to a significant increase of flavonoids and phenols contents in the plantlet. Flavonoids are frequently induced by abiotic stress and promote roles in plant protection. Several flavonoids act as potent inhibitors of the enzyme lipoxygenase, which converts polyunsaturated fatty acids to oxygen-containing derivatives (Panche et al., 2016). These compounds accumulated in plant tissue could help to protect them from damaging effects and may help to inhibit lipid peroxidation in stressed-plants (Taibi et al., 2016). On the other hand, phenolic compounds also fulfill multiple roles in plants, as structural components of cell walls, participating in the regulation of growth and developmental processes, as well as in the defense mechanisms against biotic and abiotic stress (Cheynier et al., 2013). The increase of phenolic contents in different plant tissues under salinity has also been reported in a number of plants (Valifard et al., 2014). Navarro et al. (2006) reported an increase in total phenolic content in red pepper plants under moderate salinity levels.

\section{Effect of salinity on $R W C$ and electrolyte leakage}

The effect of salinity was significant on RWC $(\mathrm{P} \leq 0.05)$ and electrolyte leakage $(\mathrm{P} \leq 0.01)$ (Table 1). RWC of the salt-treated plantlet was found to decrease with increasing salt concentration, while electrolyte leakage of the salttreated plantlet was found to increases with increasing $\mathrm{NaCl}$ concentration. In other words, salinity stress, $250 \mathrm{mM}$ $\mathrm{NaCl}$, was caused by decreasing RWC (11.33\%) and increasing electrolyte leakage (76.74\%) compared to the control treatment (Table 2).

Researchers find that the high plant power in protecting 
cellular water is one of the most important factors in maintaining survival under stress conditions. SanchezRodriguez et al. (2010) reported that the RWC is one of the best indices for differentiating sensitive and non-sensitive varieties and this parameter has a good correlation with other physiological parameters such as antioxidants and growth indices. In the present study, result demonstrated that Paneer-booti plantlet had the high level of RWC under $250 \mathrm{mM} \mathrm{NaCl}$ condition, our results indicated that Paneerbooti plantlet have a good tolerance to the salinity stress (Fig. 1). One of the reasons for this high tolerance seems to be to the increase of enzymatic and non-enzymatic antioxidant activity at high levels of salinity, which needs to be studied more exactly. Each physiological and biochemical factor in plants that plays a role in preserving the water of the plant can be one of the effective factors in introducing the cultivar. Many researchers have reported that resistant species have higher RWC than sensitive ones species (Abdallaand El-Khoshiban, 2007; Sajjadinia et al., 2010). Preserving the integrity of the cell membrane under stress conditions is an indicator of the existence of control mechanisms tolerance to dehydration. Stress causes a change in the phospholipid structure, these changes are similar to the cold stress in the fatty acid sequences, and in the salinity stress increases the unsaturated fatty acids. In severe stresses, some parts of the bilayer phospholipids of the hexagonal membrane and the structure of the membrane are converted to the ophthalmic structure and material leakage occurs. In general, salinity stress increases the lipid peroxidation and, finally, decreases the stability index cell membranes are found in different plants (Shahrifi et al., 2012). In the current study, electrolyte leakage was enhanced by increasing $\mathrm{NaCl}$ levels compared to the control treatment. This phenomenon was already observed by
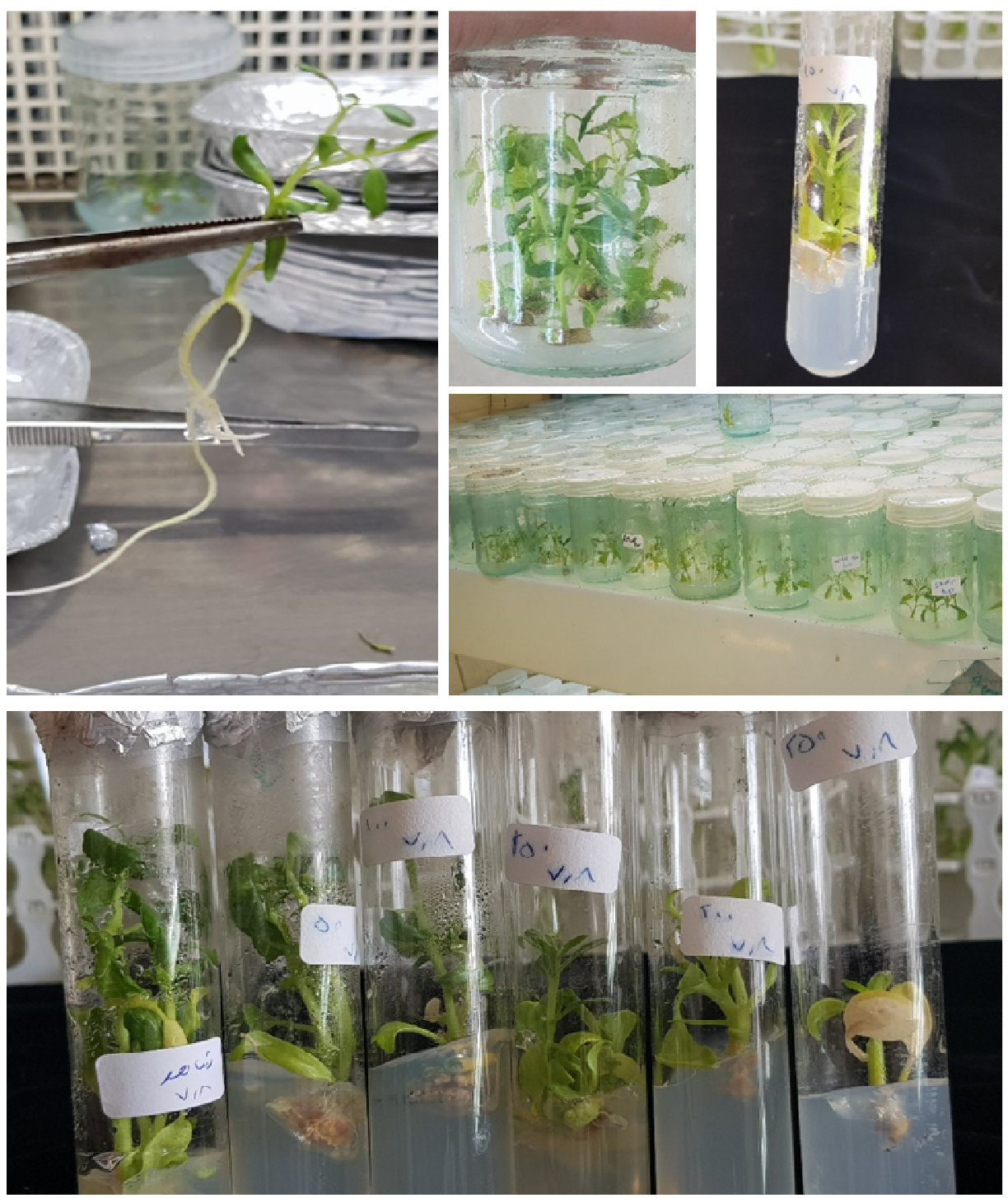

Control

$50 \mathrm{mV}$

$100 \mathrm{mM}$

$150 \mathrm{mM}$

$200 \mathrm{mM}$

$250 \mathrm{mM}$

Fig. 1. Paneer-booti (Withania coagulans Dunal) plantlet and tissue culture in the experiment 
1370

several authors Ghoulam et al. (2002) and Mumtaz-Khan et al. (2013).

\section{Effect of salinity on ionic content}

As shown in Table 3, the stressed plantlet showed significant difference according to $\mathrm{K}^{+}$and $\mathrm{Na}^{+}$ concentration and $\mathrm{K}^{+} / \mathrm{Na}^{+}$ratio traits. The $\mathrm{Na}^{+}$absorption of plantlet increased by the use of $\mathrm{NaCl}$ treatment. The increase absorption percentages were $54.70 \%$ in $250 \mathrm{mM}$ level compared to the non-stressed treatment (Table 4). The present study indicated that $50 \mathrm{mM} \mathrm{NaCl}$ was caused to increase $\mathrm{K}^{+}$concentration, while in the other $\mathrm{NaCl}$ concentration was observed to decrease concentration of the traits, however, the highest $\mathrm{K}^{+}$concentration was related to $50 \mathrm{mM}\left(21.43 \mathrm{mg} \mathrm{g}^{-1}\right)$ and lowest to $250 \mathrm{mM}\left(8.21 \mathrm{mg} \mathrm{g}^{-}\right.$ $\left.{ }^{1}\right)$ (Table 4). The results showed that the highest $\mathrm{K}^{+} / \mathrm{Na}^{+}$ ratio was achieved non-stress and $50 \mathrm{mM} \mathrm{NaCl}$ treatments ( 0.36 and 0.38 , respectively) and the lowest amount of the trait related to $250 \mathrm{mM} \mathrm{NaCl}(0.08)$. In other words, salinity was caused $77.7 \%$ decreasing this ratio compared to the control treatment (Table 4). Under salt stress condition, ion transport and content are altered. Different plants use different strategies to cope with the toxicity of $\mathrm{Na}^{+}$; some plants transport sodium to the leaves and accumulate it in the vacuole, while others extrude the sodium at the level of the roots (Tejera et al., 2006). Increasing potassium uptake is also a known strategy to counteract the entry of sodium (Taibi et al., 2016). In the current study, the enhance in $\mathrm{Na}^{+}$ concentration in plantlet under salinity was accompanied by decreases in $\mathrm{K}^{+}$concentration indicating that sodium is not being extruded but accumulated (Table 4). This finding agrees with our previous observations reporting that exposed to $\mathrm{NaCl}$ take up high amounts of $\mathrm{Na}^{+}$, whereas the content of $\mathrm{K}^{+}$is significantly reduced (Taibi et al., 2012).

The nutritional imbalance is another negative effect of $\mathrm{NaCl}$ stress on plants. Under salinity stress condition, relatively high $\mathrm{K}^{+} / \mathrm{Na}^{+}$ratio and $\mathrm{K}^{+}$content can reduce salt damage to plants, which is necessary for normal activities of organisms (Guan et al., 2013). $\mathrm{K}^{+}$is not only a key ion relative to salt tolerance (Zhu, 2003) but also the cation in most of higher plants and can regulate physiological functions, such as osmosis, ion balance, synthesis of protein, turgor pressure, and photosynthesis (Aghighi Shahverdi $e t$ al., 2017). Zeng et al. (2013) reported decrease in leaf $\mathrm{K}^{+}$ concentration in the presence of high $\mathrm{NaCl}$ levels. Similar results were obtained in the present experiment.

\section{Effect of salinity on chlorophyll fluorescence}

The effect of salinity was significant on maximum fluorescence $(\mathrm{Fm})$, minimum fluorescence (Fo), and variable fluorescence $(\mathrm{Fv})$ and the ratio of variable to maximum fluorescence (Fv/Fm) (Table 3). Maximum level $\mathrm{Fm}$ and $\mathrm{Fv}$ occured in $50 \mathrm{mM} \mathrm{NaCl}$. The $\mathrm{Fv} / \mathrm{Fm}$ ratio was significantly reduced with the increase in salinity levels, however, there was no significant difference between control, 50, and $100 \mathrm{mM}$ levels. $\mathrm{NaCl}$ stress, in $250 \mathrm{mM}$, was caused $67.5 \%$ decrease this ratio compared to the nonstress condition (Table 4). The maximum quantum efficiency of PSII photochemistry ( $\mathrm{Fv} / \mathrm{Fm}$ ratio) in the saltstressed treatments was from 0.74 to 0.24 . The significant decrease of $\mathrm{Fv} / \mathrm{Fm}$ ratio in compared to the control took place at the concentrations of 50,100,150,200, and 250 $\mathrm{mM} \mathrm{NaCl}$ (Table 4). These results correspond with AlGehani and Ismail (2016), who stated that the influence $\mathrm{NaCl}$ concentration is significant on chlorophyll fluorescence of Rocket (Eruca vesicaria ssp). According to the reports of Maxwell and Johnson (2000), the Fv/Fm ratio in the range of 0.70 to 0.84 is the approximately optimal value for many plant species. Lower values indicate that a proportion of the PSII reaction centers is damaged or inactivated, a phenomenon commonly observed in plants under stress (Hnilickova et al., 2017).

\section{Correlation between traits}

The results showed that there was significant positive or negative correlation between all traits. As shown in Table 5, the activity of antioxidant enzymes such as CAT, POD, and APX showed negative significant correlation with RWC, $\mathrm{K}^{+}, \mathrm{K}^{+} / \mathrm{Na}^{+}$ratio, $\mathrm{Fm}, \mathrm{Fv}$, and $\mathrm{Fv} / \mathrm{Fm}$ ratio. By increasing electrolyte leakage enhance in the rate of antioxidant enzyme activities (CAT, POD, and APX), proline, phenols, and flavonoids contents, and $\mathrm{Na}^{+}$concentration was

Table 3. Analysis of variance on ionic content and chlorophyll fluorescence of Paneer-booti (Withania coagulans Dunal) under salinity stress

\begin{tabular}{ccccccccc} 
& & \multicolumn{9}{c}{ Mean square (MS) } \\
\cline { 3 - 10 } S.O.V & df & $\mathrm{K}^{+}$ & $\mathrm{Na}^{+}$ & $\mathrm{K}^{+} / \mathrm{Na}^{+}$ratio & $\mathrm{Fm}$ & $\mathrm{Fo}$ & $\mathrm{Fv}$ & $\mathrm{Fv} / \mathrm{Fm}$ \\
Salinity & 5 & $64.9^{* *}$ & $1025.6^{* *}$ & $0.044^{* *}$ & $4.43^{* *}$ & $0.64^{* *}$ & $8.23^{* *}$ & $0.11^{* *}$ \\
Error & 12 & 2.58 & 15.2 & 0.0006 & 0.13 & 0.04 & 0.22 & 0.005 \\
C.V (\%) & - & 11.61 & 5.70 & 10.78 & 6.59 & 9.96 & 13.99 & 12.30 \\
\hline${ }^{* *}$ Significant at 0.01 probability levels, respectively & & & &
\end{tabular}

Table 4. Effect of salinity levels $(0,50,100,150,200$, and $250 \mathrm{mM} \mathrm{NaCl})$ on ionic content and chlorophyll fluorescence of Paneer-booti (Withania coagulans Dunal)

\begin{tabular}{|c|c|c|c|c|c|c|c|}
\hline Salinity $(\mathrm{mMNaCl})$ & $\mathrm{K}^{+}\left(\mathrm{mg} \mathrm{g}^{-1}\right)$ & $\mathrm{Na}^{+}\left(\mathrm{mgg}^{-1}\right)$ & $\mathrm{K}^{+} / \mathrm{Na}^{+}$ratio & $\mathrm{Fm}$ & Fo & Fv & $\mathrm{Fv} / \mathrm{Fm}$ \\
\hline Control & $16.16 \pm 1.8 \mathrm{~b}$ & $44.15 \pm 2.4 \mathrm{e}$ & $0.36 \pm 0.02 \mathrm{a}$ & $6.30 \pm 0.17 b$ & $1.58 \pm 0.02 \mathrm{~d}$ & $4.71 \pm 0.19 \mathrm{ab}$ & $0.74 \pm 0.01 \mathrm{a}$ \\
\hline 50 & $21.43 \pm 0.43 \mathrm{a}$ & $56.55 \pm 3.1 \mathrm{~d}$ & $0.38 \pm 0.02 \mathrm{a}$ & $7.07 \pm 0.15 \mathrm{a}$ & $1.81 \pm 0.07 \mathrm{~cd}$ & $5.26 \pm 0.11 \mathrm{a}$ & $0.74 \pm 0.007 \mathrm{a}$ \\
\hline 100 & $14.28 \pm 0.40 \mathrm{bc}$ & $64.79 \pm 2.1 \mathrm{c}$ & $0.22 \pm 0.001 \mathrm{~b}$ & $6.14 \pm 0.16 b$ & $1.98 \pm 0.05 \mathrm{c}$ & $4.16 \pm 0.11 b c$ & $0.67 \pm 0.004 \mathrm{ab}$ \\
\hline 150 & $12.34 \pm 0.43 \mathrm{~cd}$ & $68.45 \pm 1.6 \mathrm{c}$ & $0.18 \pm 0.01 \mathrm{~b}$ & $5.48 \pm 0.26 \mathrm{c}$ & $2.12 \pm 0.07 \mathrm{bc}$ & $3.36 \pm 0.29 c$ & $0.61 \pm 0.02 b$ \\
\hline 200 & $10.52 \pm 0.85 \mathrm{de}$ & $79.47 \pm 1.9 b$ & $0.13 \pm 0.01 \mathrm{c}$ & $4.48 \pm 0.26 \mathrm{~d}$ & $2.46 \pm 0.27 b$ & $2.01 \pm 0.51 \mathrm{~d}$ & $0.44 \pm 0.08 \mathrm{c}$ \\
\hline 250 & $8.21 \pm 0.65 \mathrm{e}$ & $97.47 \pm 1.7 \mathrm{a}$ & $0.08 \pm 0.007 \mathrm{~d}$ & $3.82 \pm 0.22 \mathrm{e}$ & $2.87 \pm 0.04 \mathrm{a}$ & $0.94 \pm 0.19 \mathrm{e}$ & $0.24 \pm 0.03 \mathrm{~d}$ \\
\hline LSD & 2.85 & 6.95 & 0.04 & 0.65 & 0.37 & 0.84 & 0.12 \\
\hline
\end{tabular}


Table 5. Correlation coefficients among some physiological and biochemical attributes of Paneer-booti (Withania coagulans Dunal) under salinity stress

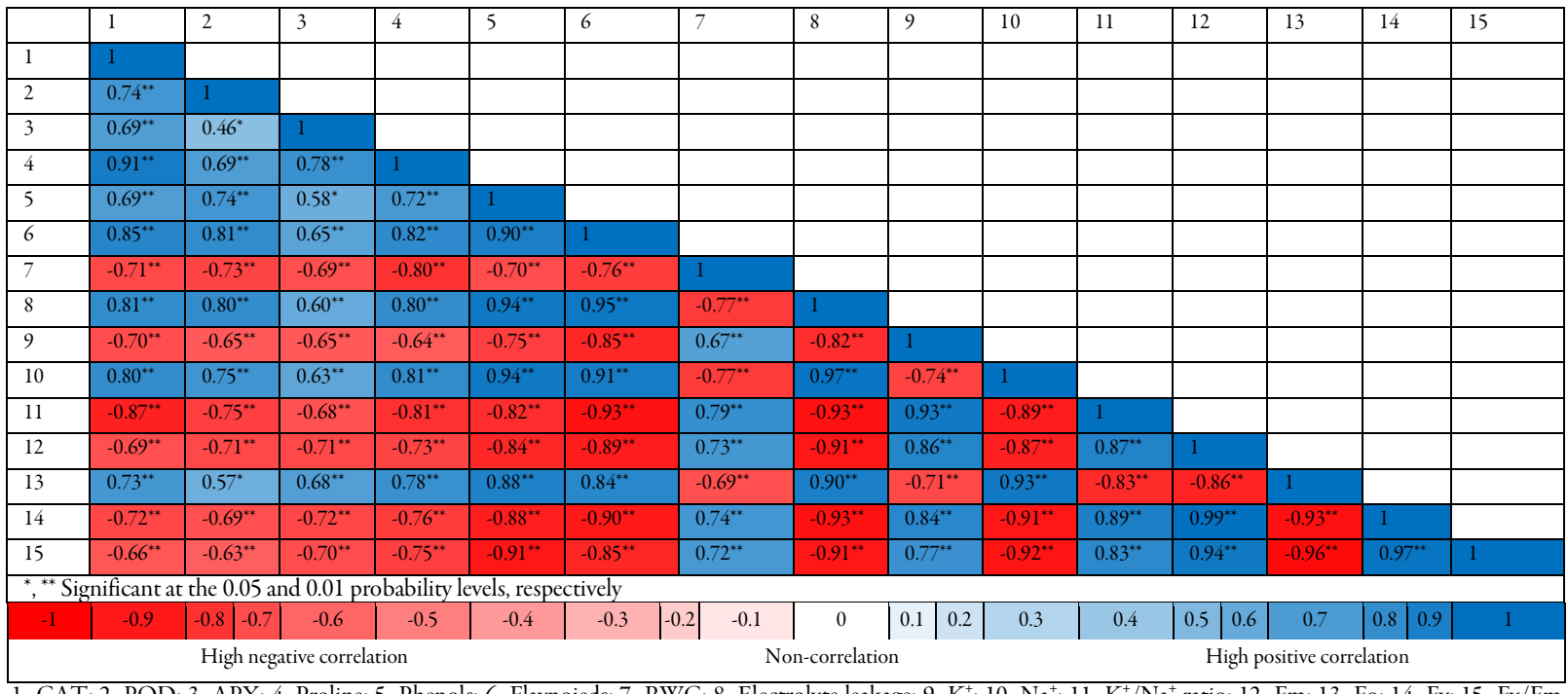
ratio

observed. In salinity stresses, the rate of $\mathrm{K}^{+} / \mathrm{Na}^{+}$ratio is very important, so, the trait had a negative correlation with antioxidant enzyme activities, proline, phenols, and flavonoids contents.

\section{Conclusions}

The aim of the present study was to assess the physiological responses such as the activity of antioxidant enzymes, RWC, ionic content, chlorophyll fluorescence of Paneer-booti plantlet to different salinity $(\mathrm{NaCl})$ stress. In this regard, results illustrated that $\mathrm{NaCl}$ had significantly increased the activity of CAT, POD, and APX, proline, phenols, flavonoids, electrolyte leakage, $\mathrm{Na}^{+}$, and Fo, while decreased RWC, $\mathrm{K}^{+}$concentration, $\mathrm{K}^{+} / \mathrm{Na}^{+}$ratio, Fm, Fv, and $\mathrm{Fv} / \mathrm{Fm}$. Results indicated that Paneer-booti plantlet had a high tolerant to the $\mathrm{NaCl}$ stress. One of the reasons for this high tolerance seems to be the increase the enzymatic and non-enzymatic antioxidant activities at high levels of salinity, which needs to be studied more exactly.

\section{Conflict of Interest}

The authors declare that there are no conflicts of interest related to this article.

\section{References}

Abdalla MM, El-Khoshiban NH (2007). The influence of water stress on growth, relative water content, photosynthetic pigments, some metabolic and hormonal contents of two Triticium aestivum cultivars. Journal of Applied Sciences Research 3(12):2062-2074.

Abdeshahian M, Nabipour M, Meskarbashee M (2010). Chlorophyll fluorescence as criterion for the diagnosis salt stress in wheat (Triticum aestivum) plants. International Journal of Chemical Engineering
71:569-571.

Abogadallah GM (2010). Insights into the significance of antioxidative defense under salt stress. Plant Signaling \& Behavior 5(4):369-374.

Aghighi Shahverdi M, Omidi H, Tabatabaei SJ (2017). Stevia (Stevia rebaudiana Bertoni) responses to $\mathrm{NaCl}$ stress: growth, photosynthetic pigments, diterpene glycosides and ion content in root and shoot. Journal of the Saudi Society of Agricultural Sciences 18(4):355-360.

Al-Gehani IA, Ismail TM (2016). Effect of soil amendment on growth and physiological processes of rocket (Eruca sativa $\mathrm{L}$.) grown under salinity conditions. Australian Journal of Basic and Applied Sciences 10(1):1520.

Alia P, Saradhi PP, Mohanty P (1991). Proline enhances primary photochemical activities in isolated thylakoid membranes of Brassica juncea by arresting photo inhibitory damage. Biochemical and Biophysical Research Communications 181(3):1238-1244.

Almedia DM, Oliveria M, Saibo NJM (2017). Regulation of $\mathrm{Na}^{+}$and $\mathrm{K}^{+}$ homeostasis in plants: towards improved salt stress tolerance in crop plants. Genetics and Molecular Biology 40(1):326-345.

Azevedo-Neto AD, Prisco JT, Eneas-Filho J, Braga de-Abreu CE, GomesFilho E (2006). Effect of salt stress on antioxidative enzymes and lipid peroxidation in leaves and roots of high-yielding and low-yielding maize genotypes. Environmental and Experimental Botany 56(1):87-94.

Bates LS, Waldern RP, Teave ID (1973). Rapid determination of free proline for water stress studies. Plant and Soil 39(1):105-107.

Blainski A, Lopes GC, de MelloJCP (2013). Application and analysis of the Folin Ciocalteu method for the determination of the total phenolic content from Limonium brasiliense L. Molecules 18(6):6852-6865.

Bybordi A (2010). The influence of salt stress on seed germination, growth and yield of canola cultivars. Notulae Botanicae Horti Agrobotanici Cluj-Napoca 38(1):128-133.

Carrasco-Rios L,Pinto M(2014). Effect of salt stress on antioxidant enzymes and lipid peroxidation in leaves in two contrasting corn, Lluteno and 
1372

Jubilee. Chilean Journal of Agricultural Research 74(1):89-95.

Chance B, Maehly C (1995). Assay of catalase and peroxidases. Methods of Enzymology 11:764-775.

Cheynier V, Comte G, Davies KM, Lattanzio V, Martens S (2013). Plant phenolics: recent advances on their biosynthesis, genetics, and ecophysiology. Plant Physiology and Biochemistry 72:1-20.

Di Ferdinando M, Brunetti C, Fini A, Tattini M (2012). Flavonoids as antioxidants in plants under abiotic stresses. In: Ahmad P, Prasad MNV (Eds). Abiotic stress responses in plants: metabolism, productivity and sustainability. Springer, New Yorkpp 159-179.

Enders A, Lehmann J (2012). Comparison of wet-digestion and dry-ashing methods for total elemental analysis of biochar. Communications in Soil Science and Plant Analysis 43(7):1042-1052.

Esfandiari E, Shekari F, Shekari F, Esfandiari M (2007). The effect of salt stress on antioxidant enzymes activity and lipid peroxidation on the wheat seedling. Notulae Botanicae Horti Agrobotanici Cluj-Napoca 35(1):48-56.

Ghoulam C, Foursy A, Fares K (2002). Effects of salt stress on growth, inorganic ions and proline accumulation in relation to osmotic adjustment in five sugar beet cultivars. Environmental and Experimental Botany 47(1):39-50.

Guan Z, Su Y, Teng N, Chen S, Sun H, Li C, Chen F (2013). Morphological, physiological and structural responses of two species of Artemisia to $\mathrm{NaCl}$ stress. The Scientific World Journal 309808.

Hnilickova H,Hnilicka F, MartinkovaJ,Kraus K(2017).Effects of salt stress on water status, photosynthesis and chlorophyll fluorescence of rocket. PlantSoil Environment 63(8):362-367.

Jafari M, Tavili A, Panahi F, Zandi Esfahan E, Ghorbani M (2018). Reclamation of aridlands. Springer Publisher.

Jaleel CA, Gopi R, Manivannan P, Panneerselvam R (2007). Antioxidative potentials as a protective mechanism in Catharanthus roseus (L.) G. Don. plants under salinity stress. Turkish Journal of Botany 31(3):245251.

Kaur L, Zhawar V (2016). Phenolic parameters under exogenous ABA, water stress, salt stress in two wheat cultivars varying in drought tolerance. Indian Journal of Plant Physiology 20(2):151-156.

Kumar Shrivastava A, Sahu PK (2013). Economics of yield and production of Alkaloid of Withania somnifera (L.) Dunal. American Journal of Plant Science 4(10):2023-2030.

Lee JH, Cho S, Paik HD, Choi CW, Nam KT, Hwang SG, Kim SK (2014). Investigation on antibacterial and antioxidant activities, phenolic and flavonoid contents of some thai edible plants as an alternative for antibiotics. Asian-Australasian Journal of Animal Sciences 27(10):14611468.

Mattioli R, Costantino P, Trovato M (2009). Proline accumulation in plants, not only stress. Plant Signaling and Behavior 4(11):1016-1018.

Maxwell K, Johnson GN (2000). Chlorophyll fluorescence A practical guide. Journal of Experimental Botany 51(345):659-668.

Mumtaz-Khan M, Al-Masoudi RSM, Al-Said F, Khan I (2013). Salinity effects on growth, electrolyte leakage, chlorophyll content and lipid peroxidation in cucumber (Cucumis sativus L.). International Conference on Food and Agricultural Sciences Malaysia: IACSIT Press pp28-32.
Navarro JM, Flores P, Garrido C, Martinez V (2006). Changes in the contents of antioxidant compounds in pepper fruits at ripening stages, as affected by salinity. Food Chemistry 96(1):66-73.

Ozgur R, Uzilday B, Sekmen AH, Turkan I (2013). Reactive oxygen species regulation and antioxidant defence in halophytes. Functional Plant Biology 40(9):832-847.

Panche AN, Diwan AD, Chandra SR (2016). Flavonoids: an overview. Journal of Nutritional Science 5:1-8.

Perry JJ, Shin DS, Getzoff ED, Tainer JA (2010). The structural biochemistry of the superoxide dismutases. Biochimica et Biophysica Acta 1804(2):245-262.

Sabir F, Sangwan RS, Kumar R, Sangwan NS (2012). Salt stress-induced responses in growth and metabolism in callus cultures and differentiating in vitro shoots of Indian ginseng (Withania somnifera Dunal).Journal of Plant Growth Regulation 31(4):537-548.

Sajjadinia A, Ershadi A, Hokmabadi H, Khayyat M, Gholami M (2010). Gas exchange activities and relative water content at different fruit growth and developmental stages of on and off cultivated pistachio trees. American Journal of Agricultural Economics 1(1):1-6.

Sanchez-Rodriguez E, Rubio-Wilhelmi M, Cervilla LM, Blasco B, Rios JJ, Rosales MA, ... Ruiz JM (2010). Genotypic differences in some physiological parameters symptomatic for oxidative stress under moderate drought in tomato plants. Plant Science 178(1):30-40.

Sangwan NS, Farooqi AHA, Sangwan RS (1994). Effect of drought on growth and essential oil metabolism in lemongrass species. New Phytologist 128(1):173-179.

Shahrifi P, Amirnia R, Majidi E, Hadi H, Roustaii M, Nakhoda B, Alipoor HM, Moradi F (2012). Relationship between drought stress and some antioxidant enzymes with cell membrane and chlorophyll stability in wheat lines. African Journal of Microbiology Research 6(3):617-623.

Shereefa LAH, Kumaraswamy M (2016). Reactive oxygen species and ascorbate-glutathione interplay in signaling and stress responses in Sesamum orientale L. against Alternaria sesami (Kawamura) Mohanty and Behera. Journal of the Saudi Society of Agricultural Sciences 15(1):48-56.

Sunohara Y, Matsumoto H (2004). Oxidative injury induced by the herbicide quinclorac on Echinochloa oryzicola Vasing and the involvement of antioxidative ability in its highly selective action in grass species. Plant Science 167(3):597-606.

Taibi K, Taibi F, Abderrahim LA, Ennjah A, Belkhodja M, Mulet JM (2016). Effect of salt stress on growth, chlorophyll content, lipid peroxidation and antioxidant defence systems in Phaseolus vulgaris L. South African Journal of Botany 105:306-312.

Taibi K, Taibi F, Belkhodja M (2012). Effects of external calcium supply on the physiological response of salt stressed bean (Phaseolus vulgaris L.). Genetics and Plant Physiology 2(2-4):177-186.

Tejera NA, Soussi M, Lluch C (2006). Physiological and nutritional indicators of tolerance to salinity in chickpea plants growing under symbiotic conditions. Environmental and Experimental Botany 58(13):17-24.

Valifard M, Mohsenzadeh S, Kholdebarin B, Rowshan V (2014). Effects of salt stress on volatile compounds, total phenolic content and antioxidant activities of Salvia mirzayanii. South African Journal of Botany 93:92- 
97.

Valizadeh J, Valizadeh M (2011). Development of efficient micropropagation protocol for Withania coagulans (Stocks) Dunal. African Journal of Biotechnology 10(39):7611-7616.

Vargas R, Pankova EI, Balyuk SA, Krasilnikov PV, Khasankhanova GM (2018). Handbook for saline soil management. Food and Agriculture Organization of the United Nations and Lomonosov Moscow State University.

Zeng J, Cheng A, Lim D, Yi B, Wu W (2013). Effects of salt stress on the growth, physiological responses, and gycoside contents of Stevia rebaudiana Bertoni. Journal of Agriculture Food Chemistry
61(24):5720-5726.

1373

Zhishen J, Mengcheng T, Jianming W (1999). The determination of flavonoid contents in mulberry and their scavenging effects on superoxide radicals. Food Chemistry 64(4):555-559.

Zhu JK (2003). Regulation of ion homeostasis under salt stress. Current Opinion in Plant Biology 6(5):441-445. 